\title{
Selfish genes and reproductive fitness
}

\section{John Launer}

The 20th century saw two key discoveries in genetics. One took place in the laboratory and established the helical structure of DNA. The other was more of an intellectual revolution: the development of selfish gene theory, also known as gene centred evolution. Most doctors will be far more familiar with the first of these discoveries than the second. They would no doubt find it easier to explain how the DNA molecule winds round in a helix and makes a mirror image of itself, than they could expand on how genes can be said to be selfish. This emphasis on the physical properties of molecules rather than abstract theoretical ideas is perhaps understandable. Knowing the structure of DNA has certainly led to fantastic advances in biological science and in medicine. However, it may also have led us to ignore a set of ideas that may in time prove to be more profound in affecting our view of ourselves as human beings. I would place a bet on future generations seeing the recognition of the selfish geneand the related concept of reproductive fitness-as an even greater scientific achievement than elaborating the spiral shape of nucleic acid.

Selfish gene theory emerged gradually in the second half of the last century through the work of people like WD Hamilton, John Maynard Smith and George Williams, but has become mostly associated with the name of Richard Dawkins. He has contributed significantly towards it, but has also popularised the theory through writing so clearly and persuasively about it. ${ }^{1}$ Dawkins is the first to admit that the term 'selfish gene' may not be the best description of how genes work, since it carries unnecessary overtones of moral judgement. Genes are not selfish in the sense that they decide how to behave. They simply do what they do, which is to replicate, survive, and then replicate again. Although Dawkins has never suggested this as alternative

Correspondence to Dr John Launer, London Deanery, London Department of Postgraduate Medical Education, Stewart House, London WC1B 5DN, UK;

jlauner@londondeanery.ac.uk term, the 'dedicated duplicator' might be a better one.

\section{GENE REPLICATION}

At the core of selfish gene theory is the idea that whole organisms are in essence the vehicles for gene replication. Each of our genes is far more ancient than any of us as individuals. If we reproduce during our lifetimes, a substantial proportion of our genes will outlast us and continue to replicate through our descendents. Another way of framing this idea is that genes rather than individuals or species are the true unit of selection and survival. In the process of evolution, it is different genes that are really competing with each other for effectiveness in terms of their ability to fit the environment each time a change occurs, or to prove attractive in terms of sexual choice. Of course, sometimes it 'suits' genes to cooperate with each other, so that a group of collaborative genes will do better if they are passed on together rather than separately. Selfish gene theory is now an accepted belief in biology. It is also counterintuitive for most people, since we normally think of ourselves in terms of our own individual identity, or in terms of species, rather than as conglomerations of genes. Potentially, it is quite a blow to our self-esteem.

If selfish gene theory challenges our view of ourselves, an even bigger challenge comes from a closely related area in biology-the study of reproductive fitness.

Biologists, of course, use the word 'fitness' not in the gymnastic sense, but in terms of the capacity to leave surviving progeny behind at one's death-progeny who will have the right attributes to 'fit' the environment in which they find themselves. This may involve developing structural adaptations over many generations such as larger brains or more dextrous hands, or it may arise through functional attributes like language, intelligence, modes of raising infants, or kinship patterns. Generally, structure and function develop in tandem anyway.

Reproductive fitness is also a retrospective judgement. One may have many children and grandchildren, for example, but if none of the great-grandchildren survive, then one's genes have in the last resort proved unfit. All that any individual can do, in that respect, is to procreate, protect the interests of the next generation, and then, as it were, keep one's posthumous fingers crossed.

\section{DEATH, SEX AND HOPE}

The best account I have ever come across of the place of reproductive fitness in evolution is a book with the wonderful title 'Death, Sex and Hope' by the Australian evolutionary ecologist John Chisholm. $^{2}$ (I would highly recommend the book to anyone who wants a comprehensive view of how a modern evolutionist pieces together the jigsaw of genes, environment, behaviour, feelings, decisionmaking, and moral judgement.) Chisholm takes the focus away from considering what is normal and what is abnormal in human life, pointing out instead that, in evolutionary terms, any variation that has survived down the generations is by definition adapted to its physical and social context. He shows how various patterns of feeling and behaviour, transmitted by genetic inheritance, family relationships, and the interaction of the two, contribute to survival and reproduction in differing environments. He also looks at how core human values, including social ones, reflect the shared interests of human groups in promoting the replication of their genes.

Chisholm considers different kinds of parent-child attachment, pair mating and family make-up as evolutionary variations, each adapted to fulfil this purpose within particular environmental circumstances. For example, he shows how, in conditions of relative deprivation, human beings will tend to start conceiving soon after puberty and have many children. Conversely, in secure circumstances, where both parents and children are more likely to survive, adults will tend to wait longer before conceiving, and will invest their resources in a smaller number of children. Neither of these approaches is particularly preferable; they are just strategies that suit different sets of circumstances.

If the biological purpose of being human is to create more humans, Chisholm points out, all adults have in effect to make continual decisions, consciously or unconsciously, about the trade-off between seeking to procreate here and now, or delaying it until later. At any moment, he suggests, sex represents an irresistible opportunity because it will create progeny 
who may outlive us if we die tomorrow (hence the urgency of sexual desire). At the same time, it represents a considerable threat because having children now may lead to a depletion of resources for the parents and a risk to their survival (hence presumably the anxiety that often surrounds the desire). This is especially the case for their mothers, who will have to nourish and look after them for years to come. However, it is also the case for fathers, who may have to offer significant parental investment as well.

\section{UNCERTAIN FUTURES}

As Chisholm argues, there are other aspects to the dilemma of managing our 'uncertain futures' as well. Having sex now may prejudice the chances of having sex later, when a fitter partner may become available, or when conditions may be more better for having babies with a reasonable chance of reaching adulthood. In the same way, having lots of babies as soon as possible may pay off in the short run in terms of numbers; however, at the same time it may take its toll on one or both parents, so that in the end the health and lives of all the family are put at risk. If this happens, they would have been better off having only one or two children. In a nutshell, we continually have to choose between sex and survival, and each prejudices the chance of the other.

Our whole range of mental, psychological, behavioural, parental and moral strategies, Chisholm proposes, are ultimately geared to addressing such trade-offs. He examines how we use our own theory of mind' to observe our thoughts and feelings, interpret those of other people, and make judgements based on our conclusions. Since we all die, but do not know when this will be, our lives are poised on the cusp of critical choices about sex versus survival. He describes how our feelings are our best way-indeed the only way-of assessing our interactions with others and with the environment, and how far these are progressing our interests. He also points out that we are not necessarily designed to have wholly pleasurable feelings, since negative experiences and an appropriate negative response are innate to our existence on the planet. "People, like all organisms," he writes, "are not evolved to maximise health, wealth, happiness, life span, vigour, power, prestige, beauty, love, sex, truth, honour, reason or anything else, but to have descendants, which is continuation." Or, as the Bible puts it intuitively, and more succinctly: "Go forth and multiply".

Competing interests None.

Provenance and peer review Commissioned; internally peer reviewed.

Published Online First 7 September 2011

Postgrad Med J 2011;87:735-736.

doi:10.1136/postgradmedj-2011-130407

\section{REFERENCES}

1. Richard D. The Selfish Gene. Oxford: Oxford University Press, 1976.

2. Chisholm J. Death, Hope and Sex: Steps to an Evolutionary Ecology of Mind and Morality. Cambridge: Cambridge University Press, 1999. 